\title{
Illustrations
}

\section{METROPOLITAN ASPECTS}

Detail of Mural in Federal Building and Post Office

Mural by Edward Biberman

Section of Fine Arts, Treasury Department

Seventh Street

$$
\text { Fred William Carter }
$$

Airview of Downtown Los Angeles, looking South

Los Angeles County Development Committee

Main Street

Fred William Carter

City Hall

Fred William Carter

\section{ARCHITECTURE}

Los Angeles County General Hospital

Viktor von Pribosic

Los Angeles Public Library

Bertram Goodhue, Architect Burton O. Burt

Mudd Memorial Hall of Philosophy, University of Southern California

University of Southern California

McAlmon Residence, Los Angeles R. M. Schindler, Architect Julius Shulman

"Blue and Silver House," the residence of Jobyna HowlandBeverly Hills

Lloyd Wright, Architect Julius Shulman

A Palm Springs Residence

Honnold and Russell, Architects Thomas \& Kitchel
Page

Between Io and $\mathrm{II}$

Los Angeles Stock Exchange "Dick" Whittington

Lotus Pool in Echo Park Frank L. Rollins

Duckpond, Westlake Park Fred William Carter

Residential District Burton O. Burt

Lafayette Park and the First Congregational Church Fred William Carter

First Sketch of Los Angeles (1852), from Fort Moore Hill Security First National Bank

Sixth and Spring Streets (1904) Security First National Bank

Between 72 and 73

V. D. L. Research House, Los Angeles

Home of Richard J. Neutra, Architect Luckhaus Studio

Federal Building and Post Office, Los Angeles

G. Stanley Underwood, Architect

F. E. Dunham: U. S. Forest Service

Columbia Broadcasting System Studios, Hollywood

William Lescaze, Architect

Columbia Broadcasting System

Edison Building, Los Angeles Allison and Allison, Architects Edison Company 
ARCHITECTURE-continued

A Sierra Madre Residence of Batten Construction

Graham Latta, Architect George D. Haight

\section{MOVIES IN THE MAKING}

The Main Studio at Burbank of Warner Brothers First National Pictures Warner Brothers

The Samuel Goldwyn Lot, Smallest of the Major Studios

Samuel Goldwyn

Whenever there's a question there's a conference

Robert Coburn

Shooting a scene on a sound stage set

Samuel Goldwyn

Completed set

Samuel Goldwyn

Shooting a scene with a Technicolor camera

Samuel Goldwyn

Lunch Time on the Set

Samuel Goldwyn

Men's Wardrobe Department

Metro-Goldwyn-Mayer

Expert seamstresses are employed Metro-Goldwyn-Mayer

\section{ART AND EDUCATION}

A Station of the Cross, Mission San Gabriel Arcangel

Index of American Design

Prometheus, Mural by Jose Orozco in Fray Hall, Pomona College, Claremont

Boyd Cooper

Loggia, Mission San Juan Capistrano

Index of American Design

Belfry, Mission San Gabriel Arcangel

Burton O. Burt

Mission San Fernando

Fred William Carter
Page

Between 72 and 73

An Altadena Residence (Monterey Style) H. Roy Kelley, Architect

George D. Haight

Between $\mathrm{I} 34$ and 135

A Corner of the Property Room Metro-Goldwyn-Mayer

Makeup Samuel Goldwyn

Fog made to order Samuel Goldwyn

A Hand-made Tree Samuel Goldwyn

Waves are produced by motordriven eccentric cylinders

Samuel Goldwyn

Vegetables are shellacked to prevent wilting under heat of lights

Samuel Goldwyn

A modern moviola is used in the process of editing, or "cutting," the film

Samuel Goldwyn

Music is synchronized on records which are played back later and recorded on film.

Robert Coburn

Between 164 and 165

Detail from Painting, Rancho La Brea Pitch Pools

Field Museum of Natural History, Chicago

Imperial Elephant, Los Angeles Museum of History, Science, and Art

Theodore Baron

In the Planetarium, Griffith $\mathrm{Ob}$ servatory, Los Angeles

Fred William Carter

Young Public School Artist

Board of Education, Los Angeles 
I L L U S T R T I O N Si

ART AND EDUCATION-continued

Experimental Public School, Los Angeles

Richard J. Neutra, Architect Luckhaus Studio

Thomas Jefferson High School, Los Angeles

Stiles O. Clement, Architect Board of Education, Los Angeles

\section{INDUSTRY AND COMMERCE}

Unloading tuna fish, Fish Harbor,

Terminal Island Burton O. Burt

Loading ship, Terminal Island Burton O. Burt

Grain Elevator Bret Weston

Natural Gas Tanks Bret Weston

Oil Fields, Montebello Fred William Carter

Airview of Industrial Section, Los

Angeles Spense Air Photos

Wine Storage Vats Los Angeles County Chamber of Commerce

\section{RECREATION}

Tournament of Roses Parade, Pasadena

Bathing Beauty Parade, Venice Mardi Gras

Surf Board Riding, Hermosa Beach

Los Angeles County Chamber of Commerce

Bathing Scene at Long Beach Inman Company

Sailing, Alamitos Bay Los Angeles County Chamber of Commerce

Marlin Swordfish (570 lbs.), Catalina

Santa Catalina Island
Between 226 and 227

Wine Experts Taste and Classify California Vintages

In a Walnut Packing Plant Art Streib

Lemon Sizing Machine

California Fruit Growers' Exchange

Body Assembly Line, Automobile

Factory

Studebaker-Pacific Corporation

Assembly Room, Aircraft Factory Douglas Aircraft Company, Inc.
Between 256 and 257

Ice Hockey on Jackson Lake, Big Pines Park

Los Angeles County Chamber of Commerce

Tobogganing in Big Pines Park Los Angeles County Chamber of Commerce

Skiing at Big Pines Park Los Angeles County Chamber of Commerce

Dog Sled, Arrowhead Lake Lake Arrowhead Company

Fishing off the Pier, Santa Monica Fred William Carter

Card Players in the Park Burton O. Burt 
RECREATION-continued

Bowling on the Green, Exposition Park, Los Angeles Burton O. Burt

Tennis Courts, La Cienega Playground, Beverly Hills City of Beverly Hills

\section{STREET SCENES}

In the Old Plaza

Burton O. Burt

Debate in Pershing Square Burton O. Burt

Unpacking "huacales" (Mexican packing cases), Olvera Street Viroque Baker

"La Vieja" (The Old Lady), Olvera Street Viroque Baker

Mexican Blacksmith, Olvera Street Burton O. Burt

Mexican Potters' "Priesto," Olvera Street Burton O. Burt

Chinese Market Burton O. Burt

Mexican Market Burton O. Burt

\section{ALONG THE HIGHWAY}

North Shore, Santa Monica Bay Fred William Carter

Palm Canyon, Palm Springs Fred William Carter

Joshua Tree Burton O. Burt

San Fernando Valley from Mulholland Drive Burton O. Burt

Mt. San Jacinto Fred William Carter

Grapefruit Grove California Fruit Growers' Exchange

Roping Cattle Theodore Baron
Page

Between 256 and 257

Hollywood Park Race Track, Inglewood Carroll Photo Service

Airview, Rose Bowl, Pasadena Kopec Photo Company

Between 318 and 319

Mexican News Stand, North Main Street Burton O. Burt

Japanese News Stand, East First Street Burton O. Burt

Angelus Temple Burton O. Burt

Flop House and "Nickel Show," Main Street Burton O. Burt

A Rushing Business Burton O. Burt

The Record of the Stars, Grauman's Chinese Theater Burton O. Burt

The Brown Derby (Wilshire Boulevard)

Fred William Carter.

Parasol Library in Pershing Square

Fred William Carter

Between 380 and $38 \mathrm{I}$

Sheep

Horace Bristol

Casa Verdugo, Glendale

Burton O. Burt

Shinto Temple in Japanese Fishing Village, Terminal Island Burton O. Burt

Lasky's Barn, Hollywood-First Home of Paramount Pictures Theodore Baron

Old Lugo House on the Plaza, Los Angeles

Viroque Baker

Portuguese mending nets, Terminal Island Viroque Baker 